Article

\title{
The Importance of Microtopography and Nurse Canopy for Successful Restoration Planting of the Slow-Growing Conifer Pilgerodendron uviferum
}

\author{
Jan R. Bannister ${ }^{1, *}$, Rafael E. Coopman ${ }^{2}$, Pablo J. Donoso ${ }^{2}$ and Jürgen Bauhus ${ }^{1}$ \\ 1 Chair of Silviculture, Faculty of Environment and Natural Resources, Albert-Ludwigs University, \\ Tennenbacherstrasse 4, Freiburg, D-79106, Germany; \\ E-Mail: juergen.bauhus@waldbau.uni-freiburg.de \\ 2 Institute of Silviculture, Universidad Austral de Chile, Casilla 567, Valdivia, 5090000, Chile; \\ E-Mails: rafael.coopman@uach.cl (R.E.C.); pdonoso@uach.cl (P.J.D.) \\ * Author to whom correspondence should be addressed; \\ E-Mail: jan.bannister@waldbau.uni-freiburg.de; Tel.: +49-0761-203-8622; \\ Fax: +49-0761-203-3781.
}

Received: 4 November 2012; in revised form: 20 December 2012 / Accepted: 7 January 2013 / Published: 16 January 2013

\begin{abstract}
Recent studies have shown that, owing to a lack of seed trees, the natural rate of recovery of fire-disturbed bog forests previously dominated by the endemic and endangered conifer Pilgerodendron uviferum (D. Don) Florin is extremely slow. Hence, increasing the number of seed trees in the landscape through restoration planting could remove the principal biotic filter, limiting recovery of these forests. Here, we analyzed how the success of restoration plantings may be improved through the choice or manipulation of microsites in P. uviferum forests on Chiloé Island in North Patagonia. For this purpose, we manipulated microtopography in water-logged sites in bogs (mounds, flat terrain, mineral soil) and changed canopy conditions (gaps, semi-open, closed canopy) in upland sites with better drainage. In bogs, there was no significant effect of microtopography on growth and survival of $P$. uviferum plantings. However, fluorescence measurements indicated lower stress in seedlings established on mounds. Seedlings in upland areas established beneath a nurse canopy had lower mortality and higher relative shoot growth, foliar nutrients, photosynthetic light use efficiency and chlorophyll fluorescence values than those planted in the open. This indicates that seedlings of the slow growing P. uviferum can tolerate extremely wet conditions, yet suffer from stress when grown in the open. Here, the
\end{abstract}


removal of canopy appeared to have also removed or reduced mycorrhizal networks for seedlings, leading to poorer nutrition and growth. Based on these results, recommendations for restoration plantings in highly degraded P. uviferum forests are presented.

Keywords: active restoration; conifer bog forests; Chiloé Island; North Patagonia; seedling growth; Sphagnum

\section{Introduction}

Successful restoration of degraded ecosystems often depends on the removal of the influences leading to degradation, but this will not always be sufficient to achieve the desired restoration [1]. Generally, forest restoration has been divided into "passive" and "active" approaches, where the former comprises removal of environmental stressors and use of successional processes to restore ecosystems and the latter refers to artificial regeneration through planting or sowing, burning and/or thinning to achieve or promote the desired structure or development $[2,3]$. The intrinsic ecosystem resilience to disturbance, the level of ongoing human degradation and the characteristics of the landscape are the principal factors affecting the natural rate of recovery of ecosystems, hence, they need to be known to identify a suitable restoration approach [4].

The present study aims to contribute to this knowledge for Pilgerodendron uviferum (D. Don) Florin forests in the Chilean Patagonia, which have been highly degraded in the past. Pilgerodendron uviferum occurs in bog forests in high rainfall environments $(2500-8000 \mathrm{~mm}$ per year) that cover almost 1 million ha from $40^{\circ} \mathrm{S}$ to $55^{\circ} \mathrm{S}$ and are often found on acidic and poorly-drained soils [5]. The dominant species $P$. uviferum, is an endemic, slow-growing, long-lived, decay-resistant and high-value conifer species [6]. During the last two centuries, humans have destroyed extensive areas of these forests through broad-scale burning to facilitate access to $P$. uviferum dead trees [7]. The precise extent of the disturbance and loss of the original area of $P$. uviferum forests is unfortunately not known. In the landscape of Chiloé and other areas of Patagonia, P. uviferum dominated forests are located in two topographical types: "bog areas" located in flat areas on raised peat bogs; and "upland areas" on hills shaped by till with better drainage [6]. Recent studies have shown that the natural rate of recovery of fire-disturbed bog forests previously dominated by P. uviferum is limited by the low number of seed trees that survived disturbance or emerged post disturbance [6]. Even in forests burnt 70 years ago, these bog forests are recovering at extremely slow rates and P. uviferum is still absent in large tracts of the landscape [6,7]. Accordingly, the conservation status of the species considered by the IUCN is vulnerable [8], and it has been included in Appendix I of CITES [5].

In this context, increasing the number of $P$. uviferum seed trees in the landscape through restoration planting in both, bog and upland areas, could remove the principal biotic filter [9], which is currently retarding the natural recovery of these forests [10]. Unfortunately, there is very little experience with active restoration plantings in forests with this slow growing conifer species. The only published results from a restoration experiment with $P$. uviferum in bog areas show that survival of planted seedlings was higher on sites with less Sphagnum cover [11,12]. Similarly, in bog forests dominated 
by another long-lived conifer, Fitzroya cupressoides (Molina) I. M. (41 $\left.{ }^{\circ} \mathrm{S}\right)$, survival of planted seedlings did not depend on soil moisture, but on sites with better drainage, growth of seedlings was improved as a result of reduced Sphagnum competition [13]. In these environments, survival and growth of seedlings may depend in particular on microsite drainage, which influences waterlogging and, thus, potentially direct stress to seedlings, as well as competition with Sphagnum mosses. In Scandinavian bog forests, microhabitat was the main factor for seed emergence of Picea abies, and the most important factor for seedling mortality was competition with bryophytes [14]. In these Scandinavian bog forests, the risk of waterlogging was lower on hummocks and elevated microsites, which therefore represented safer sites for germination of $P$. abies seedlings [14]. However, only seedlings with "rapid" height growth were able to stay ahead of the upward growth of Sphagnum [15]. In northern Patagonia, this over-growing by bryophytes has also been reported for Drimys winteri seedlings of successional shrublands with waterlogged conditions [16] and for P. uviferum seedlings in undisturbed bog forests [6]. In addition, owing to the accumulation of peat and retarded decomposition of organic matter, nutrient deficiencies, in particular for $\mathrm{N}$ and $\mathrm{P}$, are typical for plants growing on bogs [17]. Thus, creation of mounds to improve drainage and reduce competition with Sphagnum or removal of the moss layer in bogs to improve nutrient uptake may be useful site preparation options for restoration plantings with $P$. uviferum.

Although drainage appears to be a relevant factor for the performance of $P$. uviferum seedlings in bogs, light may be the limiting factor in upland areas with better soil drainage, where the post-fire regrowth of broadleaved pioneer species, like Tepualia stipularis, Nothofagus nitida, D. winteri and Weinmannia trichosperma, inhibits the growth of $P$. uviferum seedlings, resulting in a gradual decline of the species [7,18]. In this context, removal of canopy to create gaps or semi-open areas for $P$. uviferum seedlings may be a useful option to establish the species in upland areas. Photosynthesis is strongly related to seedling performance and has a high responsiveness to environmental conditions $[19,20]$. However, recent findings show that $P$. uviferum seedlings planted in bogs under the shade of shrubs and ferns grew taller and had higher survival than in open areas [12]. In addition, growth of $P$. uviferum seedlings in disturbed and undisturbed forests was not related to light availability in both bog and upland sites [6]. The physiological adaptations of seedlings to high light environments may comprise higher $\mathrm{C}$ costs associated with photo-protection, higher metabolic cost and concomitant higher respiration rates of seedlings growing in the open [21]. Therefore, slow-growing species of late-successional forest development phases with the ability to grow at low light levels may suffer from high irradiance and temperature extremes in the open [21].

Here, we established two separate experiments in disturbed bog and upland forests previously dominated by $P$. uviferum. In bogs, we hypothesized that in elevated microsites with improved drainage and reduced competition from Sphagnum, planted $P$. uviferum seedlings will have (i) higher relative growth and survival and (ii) lower physiological stress than seedlings planted on mineral soil below the original surface. In the case of upland areas, we hypothesized that beneath a nurse canopy, planted P. uviferum seedlings will have (iii) higher relative growth and survival and (iv) lower physiological stress than seedlings planted in the open. To address these four hypotheses, we evaluated the performance of planted $P$. uviferum seedlings under different substrate and light conditions and analyzed the foliar nutrients of seedlings and the relationship between seedling growth and 
photosynthetic traits. Based on our results, we present recommendations for restoration plantings in highly degraded $P$. uviferum forests.

\section{Experimental Section}

\subsection{Study Area}

The study area was located in Tantauco Park $\left(\sim 43^{\circ} 10^{\prime} \mathrm{S}\right.$ and $\left.74^{\circ} 05^{\prime} \mathrm{W}\right)$ in the south of Chiloé Island, North Patagonia (Figure 1). This private biodiversity conservation area of 118,000 ha contains extensive disturbed areas of previously P. uviferum-dominated bog forests that were burnt mainly in an extensive fire of anthropogenic origin in 1943 [7,22]. Field sites were located in the disturbed forests around Lake Chaiguata.

Figure 1. Study area in Tantauco Park on Chiloé Island, North Patagonia. Gray color corresponds to Pilgerodendron uviferum dominated forests. Dark patches correspond to lakes.
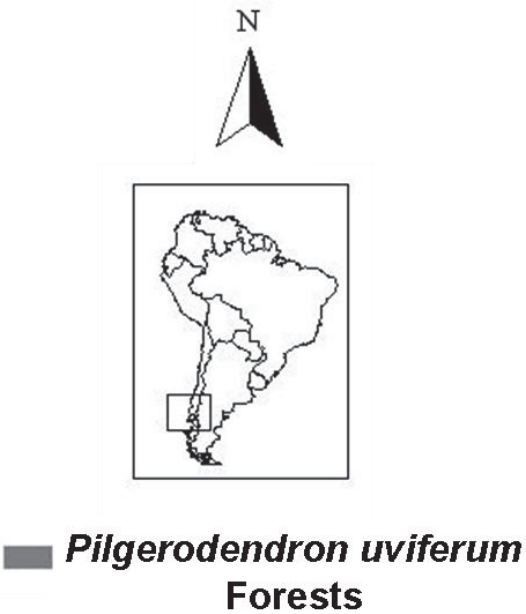

Forests

STUDY AREA TANTAUCO PARK
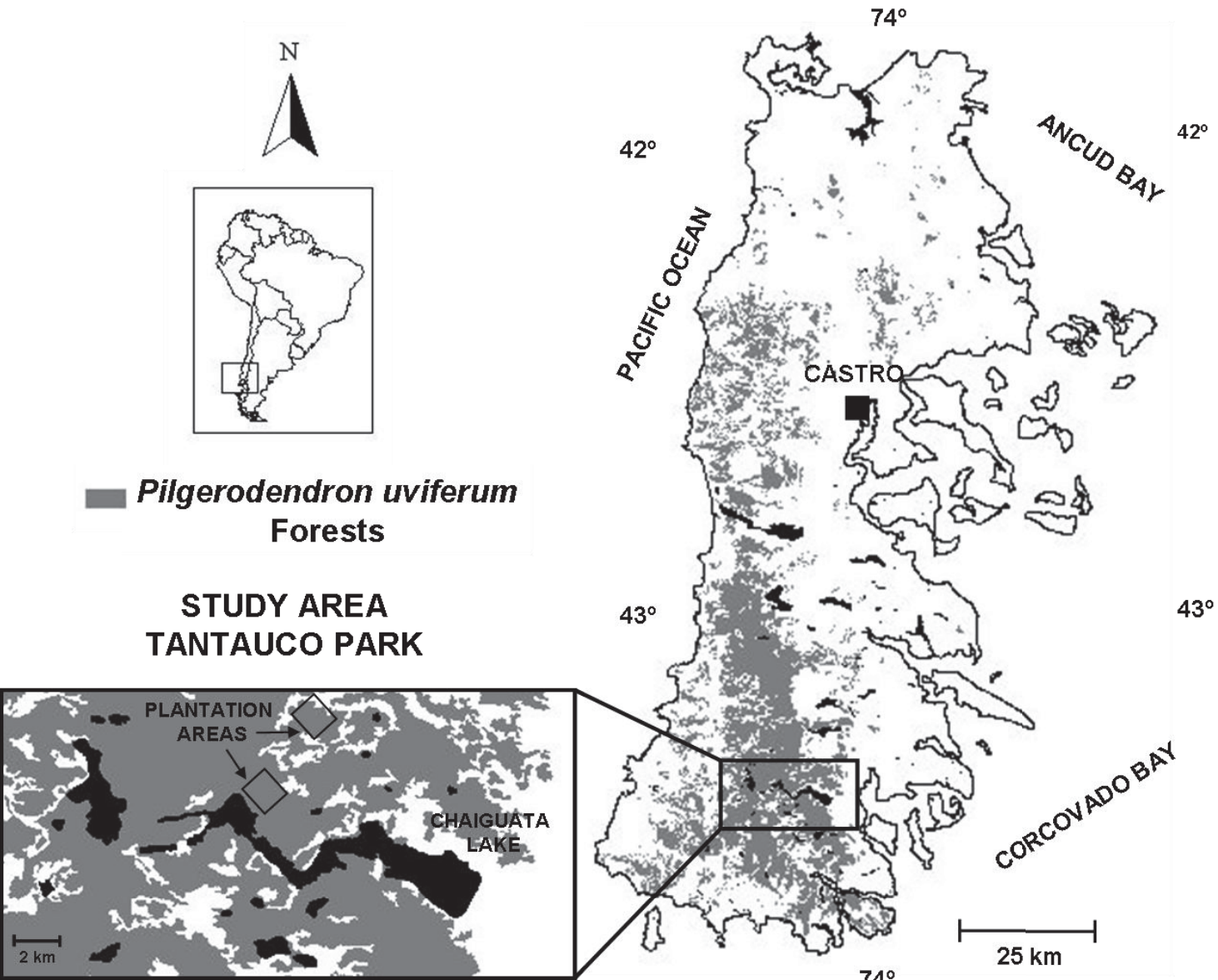

Southern Chiloé has a cool-temperate climate with strong oceanic influence and a mean annual temperature of $10{ }^{\circ} \mathrm{C}$, belonging to the south temperate biogeographic region of Chile [23,24]. Annual precipitation is high, reaching up to $6000 \mathrm{~mm}$ in some places [25], and the altitudes range between 150 and $280 \mathrm{~m}$ a.s.l. The landscape in the study area has been shaped by the last glaciation (ca. 13,000 year, BP), which created a mix of hills from glacial till and shallow valleys, over 
Pre-Cambrian and Tertiary Metamorphic rocks. The soils are extremely acidic, poorly drained and with Gley horizons [26].

Generally, the disturbed forests of the study area can be divided in two topographical types: "bog areas" located in flat areas on raised peat bogs covered by Sphagnum and cushion plants; and "upland areas" on hills shaped by till with better drainage, but also some presence of Sphagnum and other bryophytes (Figure 2a). Both types were characterized by dead trees of P. uviferum and T. stipularis, with some regrowth of broadleaved species, like $T$. stipularis, $N$. nitida, D. winteri and $W$. trichosperma. We assumed that in bogs, the limiting factor for growth is the microtopography (raised mounds with better drainage versus depressions with at least seasonal water-logging), and in upland areas, the limiting factor is light availability. It would not have been possible to establish a fully factorial design, since in bogs, there were no situations with a nurse canopy of broadleaved species, and on upland sites, there were no depressions creating water-logged situations.

\subsection{Planting Design and Implementation}

In order to evaluate the effect of the microtopography in bogs and, in upland areas, the effect of light availability on the growth and survival of $P$. uviferum seedlings, we used in both cases a randomized complete block design consisting of three treatments replicated in three blocks (Figure 2a,b). Treatments were assigned to $120 \mathrm{~m}^{2}$ experimental units, with 12 P. uviferum seedlings planted every $2 \times 2 \mathrm{~m}$, including a $3 \mathrm{~m}$ buffer around the perimeter of the unit (total of 216 seedlings). In bogs, the microtopographies into which seedlings were planted comprised the treatments: (a) BF-Min: mineral soil below the original surface after removal of the moss layer; (b) BF-Flat: undisturbed flat Sphagnum layer; and (c) BF-Mound: elevated mound (ca. $40 \mathrm{~cm}$ high and $6 \mathrm{~m}$ long), raised through the addition of the moss from treatment (a). Prior to planting, some shrubs (Baccharis sp., Gaultheria sp.) and ferns (Gleichenia sp.) were removed to ensure homogeneous light conditions for the seedlings. In upland areas, the treatments representing different canopy/light environments were: (a) UF-Gap: small open areas with a mean photosynthetic photon flux density (\%PPFD) of 78.2\%; (b) UF-50: semi-open areas, where 50\% of canopy trees were thinned (mean: $37.6 \%$ PPFD); and (c) UF-Den: 100\% canopy cover (mean: $10.9 \%$ PPFD).

Figure 2. (a) Seedlings of $P$. uviferum established in disturbed bogs on mounds; (b) Seedlings of $P$. uviferum established in disturbed upland areas beneath a closed canopy.

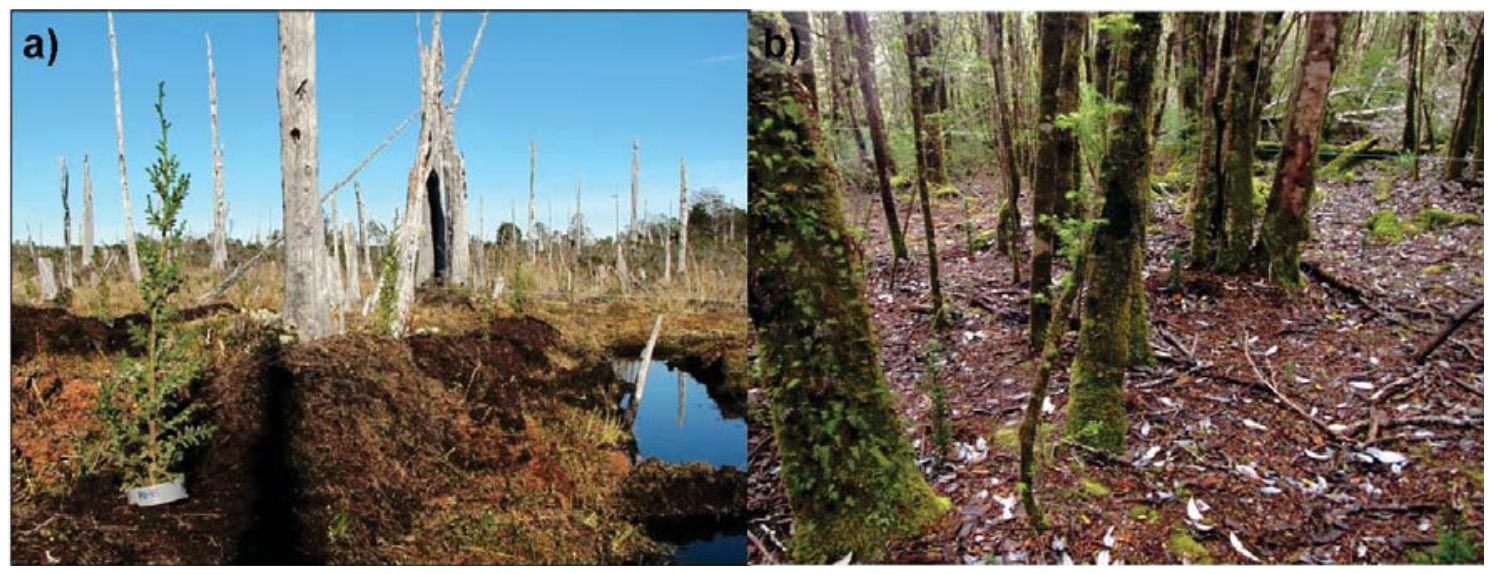


Since there was no seedling stock from local genetic sources available, the 216 P. uviferum seedlings used in this study came from seeds collected in the Coastal Mountain Range near Valdivia $\left(40^{\circ} \mathrm{S}\right)$, where there are in general similar site conditions to the study area [27]. Still, we had to assume that the planting stock was well adapted to the site. Seeds were raised in the nursery of the Department of Silviculture at the Universidad Austral in Valdivia. In the first year, seedlings had been grown in 24 cc. containers in a greenhouse and, subsequently, in a nursery bed for four additional years. These 5 -year old bare-root seedlings with a mean height of $47.3 \mathrm{~cm}$ were planted in the study area during the winter of the year 2009.

\subsection{Data Collection}

In 2009, all planted seedlings were labeled and their root collar diameter (RCD) and total height (H) measured. Seedlings were monitored over the following 2 years by measuring their height, RCD and length of the last annual shoot (SG) in winter. Mortality and survival rates were recorded, and the surviving seedlings were further divided into "live-unbrowsed" and "live-browsed". Living seedlings with any sign of browsing ( $\geq 1$ browsed branch) were included in the second group. Relative basal area growth $\left(\mathrm{cm}^{2} \mathrm{~cm}^{-2}\right)$ of each seedling was calculated according to the formula [(G2011 - G2009)/G2009], where G2009 and G2011 are the basal area $\left(\mathrm{cm}^{2}\right)$ of each seedling in the year 2009 and 2011, respectively. Relative mean shoot growth $\left(\mathrm{cm} \mathrm{cm}^{-1}\right)$ of each seedling was calculated according to the formula $[($ SG2010/H2009) + (SG2011/H2010)]/2, where SG2010 and SG2011 is the shoot growth (cm) of each seedling in 2010 and 2011, respectively and H2009 and H2010 is the total height (cm) of each seedling in 2009 and 2010, respectively. For growth analysis, we have excluded live-browsed and dead seedlings.

Light availability for seedlings within upland experimental units was determined based on the one-point overcast sky condition method [28], which considers the percentage photosynthetic photon flux density (PPFD: $\mu \mathrm{mol} \mathrm{m} \mathrm{m}^{-2} \cdot \mathrm{s}^{-1}$ ) reaching each seedling in relation to a simultaneous PPFD measured in an open area (\%PPFD). In 2009 and 2011, we measured \%PPFD immediately above the terminal shoot of the seedlings with a LICOR 1400 Data logger and LI250 point quantum sensors. In 2011, 4 needle samples from the top of 3 living seedlings were collected for nutrient analysis in each unit. Prior to analysis, needle samples were finely grounded in a swing ball mill (MM301, Retsch, Haan, Germany) and digested with concentrated nitric acid [29]. Element concentrations in the digests were quantified with ICP-OES. Total organic $\mathrm{C}$ and $\mathrm{N}$ were measured using a Leco Truspec ${ }^{\mathbf{T M}} \mathrm{CN}$ analyzer (St. Joseph, MI, USA).

\subsection{Net Photosynthesis and Chlorophyll Fluorescence Measurements}

Net $\mathrm{CO}_{2}$ assimilation at different light intensities (2000, 1200, 800, 600, 400, 300, 200, 100, 50, 25, 15 and $0 \mu \mathrm{mol}$ photons $\mathrm{m}^{-2} \cdot \mathrm{s}^{-1}$ ) was measured for 5 seedlings in each treatment of one randomly selected "upland" block with an infrared gas analyzer (LI-6400; Li-Cor, Inc., Lincoln, NE, USA) with an integrated fluorescence chamber head (LI-6400-40; Li-Cor, Inc., Lincoln, NE, USA). $\mathrm{CO}_{2}$ reference concentration was $400 \mathrm{ppm}$, with a flow rate of $350 \mathrm{~mL} \cdot \mathrm{min}^{-1}$ and a relative humidity of $69 \% \pm 8 \%$ inside the leaf chamber. The temperature of the shoot was maintained at $17 \pm 3{ }^{\circ} \mathrm{C}$. Light compensation point (LCP), light saturation point (LSP), maximal rate of net $\mathrm{CO}_{2}$ assimilation $\left(A_{\max }\right)$ 
and dark respiration $\left(R_{\mathrm{d}}\right)$ were calculated with the Photosynthesis software (Li-Cor, Inc., Lincoln, NE, USA). In order to find the best match between photosynthetic responses and growth, we evaluated correlations between: net $\mathrm{CO}_{2}$ assimilation $\left(A_{\mathrm{N}}\right)$, transpiration $(\mathrm{Tr})$, instantaneous water use efficiency $\left(\mathrm{WUE}_{\mathrm{i}}\right)$ and photosynthetic light use efficiency (PLUE) and growth at different light intensities (200 and $1200 \mu \mathrm{mol}$ photons $\mathrm{m}^{-2} \cdot \mathrm{s}^{-1}$ ). $\mathrm{WUE}_{\mathrm{i}}$ and PLUE were calculated as: $\mathrm{WUE}_{\mathrm{i}}=\left[A_{\mathrm{N}} / T_{\mathrm{r}}\right]$ and PLUE $=\left[A_{\mathrm{N}} / \mathrm{PPFD}\right]$. In case the shoot did not cover the entire leaf cuvette surface $\left(2.0 \mathrm{~cm}^{2}\right)$, a digital photograph of the shoot was taken immediately after the measurement in order to estimate the actual shoot area using ImageJ software (Rasband, W.S., NIH, Bethesda, MD, USA). Gas exchange values given by LI-6400 were corrected using the ratio between cuvette area and actual shoot area as a correction factor. Shoot dry mass was obtained after 2 days of drying at $70{ }^{\circ} \mathrm{C}$, and leaf mass area (LMA) was calculated as the ratio between dry weight $(\mathrm{g})$ and shoot area $\left(\mathrm{m}^{2}\right)$.

The potential photochemical quantum yield of photosystem II (Fv/Fm) was measured in 5 seedlings per treatment of the same selected "upland" block and also in one randomly selected block on the bog. The measurements were made according to [30], where the minimal fluorescence (Fo) was determined by applying a weak modulated light $\left(0.4 \mu \mathrm{mol} \mathrm{m} \mathrm{m}^{-2} \cdot \mathrm{s}^{-1}\right)$. Maximal fluorescence (Fm) was induced by a short pulse $(0.8 \mathrm{~s})$ of saturating light $\left(9000 \mu \mathrm{mol} \mathrm{m} \mathrm{m}^{-2} \cdot \mathrm{s}^{-1}\right)$ and $(\mathrm{Fv})$ was the variable fluorescence $(\mathrm{Fv}=\mathrm{Fm}-\mathrm{Fo})$. In the "upland" treatments, photosynthesis measurements were performed from 9:00 to 13:00 h, and in the "bog" treatments, the Fv/Fm values were recorded between 15:00 and 16:30 h, in both cases after $30 \mathrm{~min}$ of darkness on young, fully expanded shoots.

\subsection{Data Analysis}

Based on Shapiro-Wilk W, Kolmogorov Smirnov and Levene tests, all data of relative basal area growth, relative mean shoot growth, light and element concentrations were normally distributed and had homogeneity of variances. Thus we compared treatments with a two-level nested ANOVA and post hoc LSD tests. Since reported values of photosynthesis and fluorescence were measured only in one randomly selected block, these represent pseudoreplications of the same treatment and site conditions [31]. Hence, we only compared them between treatments using descriptive statistics. However, the block in which measurements were carried out was representative of the variance observed in the landscape (e.g., forest structure). Values for mortality, browsing and seedling survival exhibited heteroscedasticity or non-normal distributions even after various transformations. Thus, for comparisons among treatments, Kruskal-Wallis tests were performed, followed by post-hoc comparisons based on Mann Whitney U-tests and the Bonferroni method. In all cases, differences between values were considered significant at $p<0.05$.

Pearson's correlation and linear regressions were used to test for relationships between relative basal area growth and \%PPFD and between relative mean shoot growth and \%PPFD of P. uviferum seedlings. We also used Pearson's correlation to explore the relationships between seedling growth and photosynthetic traits measured at different light intensities. We used SPSS v.17.0 package [32] for the following analyses: Shapiro-Wilk, Kolmogorov Smirnov, Levene tests, one-way ANOVA, Kruskal-Wallis, Mann Whitney U-tests, Pearson's correlation and linear regressions. We used the "stats" package of R [33] for the two-level nested ANOVA. 


\section{Results}

\subsection{Performance of P. uviferum Seedlings in Bogs}

Mortality and survival of $P$. uviferum seedlings in bogs were highly variable within treatments, hence there was no significant effects of substrate type (Figure 3a). However, seedlings established over mounds had lower mortality (up to 8.3\%) than the other microtopographies (BF-Flat: up to 25\%; BF-Min: up to 58.3\%). Browsing by the Pudu deer (Pudu pudu) occurred in all treatments, but this problem was slightly higher in seedlings planted on mounds (up to $58 \%$ of seedlings).

Diameter growth of $P$. uviferum seedlings was extremely slow (mean $0.20-0.33 \mathrm{~cm}^{-1} \mathrm{rar}^{-1}$ ) over the two years after planting. Likewise, shoot elongation was very limited (mean $2.5-4.7 \mathrm{~cm} \mathrm{year}^{-1}$ ). Microtopography did not have a significant effect on basal area and shoot growth of seedlings (Figure 3b,c). Nevertheless, this factor had a significant effect on the $\mathrm{P}$ concentration of needles $(p \leq 0.05$ ), but no effect on the $\mathrm{N}$ concentration and the $\mathrm{N} / \mathrm{P}$ ratio (Figure $3 \mathrm{~d}, \mathrm{e}, \mathrm{f}$ ). Needle $\mathrm{P}$ concentrations of seedlings planted in an undisturbed Sphagnum layer where higher than in seedlings planted in depressions and on mineral soil $(p \leq 0.05)$. Needle P concentrations in seedlings established on mounds ranged between these two treatments. Foliar N:P ratios were low in all three treatments and less than 14, which typically indicates $\mathrm{N}$ limitation [34].

In addition, seedlings established on mounds had higher potential photochemical quantum yield of photosystem II (Fv/Fm) than seedlings planted in undisturbed Sphagnum layers and in mineral soil (BF-Mou: $0.77 \pm 0.04$; BF-Flat: $0.71 \pm 0.03$; BF-Min: $0.69 \pm 0.03$ ). Considering seedlings of all three treatments, there was a highly significant positive correlation $(r=0.83 ; p<0.01)$ between relative mean shoot growth of seedlings and the potential photochemical quantum yield of photosystem II (Fv/Fm).

\subsection{Performance of P. uviferum Seedlings in Upland Areas}

As in bogs, in upland areas, mortality and survival of $P$. uviferum seedlings were also highly variable within treatments, hence there was no significant effect of light availability (Figure 4a). In upland areas, no mortality occurred amongst seedlings established beneath the canopy of existing stands (UF-50 and UF-Den). Browsing by the Pudu deer (Pudu pudu) occurred in all treatments, but was substantially higher for seedlings planted in gaps (up to $100 \%$ of seedlings).

Diameter growth of $P$. uviferum seedlings was also particularly slow (mean $0.15-0.26 \mathrm{~cm} \mathrm{year}^{-1}$ ) over the two years after planting, and shoot elongation was low (mean 2.9-8.6 $\mathrm{cm}^{\text {year }}{ }^{-1}$ ). In upland areas, different canopy densities had no significant effect on relative basal area growth of seedlings, but had a significant effect on relative shoot growth $(p<0.001)$ (Figure $4 \mathrm{~b}, \mathrm{c})$. Shoot elongation of seedlings was highest under complete canopy cover and lowest under the most open conditions in gaps $(p \leq 0.001)$. In addition, needle $\mathrm{P}$ and $\mathrm{N}$ concentrations were highest in treatments offering canopy cover to seedlings (UF-Den and UF-50) $(p \leq 0.001)$. The needles of seedling established in gaps had the lowest foliar P and N concentrations and the highest N/P values (Figure 4d,e,f). Like in bogs, in upland areas, foliar $\mathrm{N}: \mathrm{P}$ ratios were low in all treatments, indicating $\mathrm{N}$ limitation. Considering seedlings of all three treatments, there was a highly significant negative correlation $(p<0.001)$ between relative mean shoot growth of $P$. uviferum seedlings and the \%PPFD immediately above their 
terminal shoot, but the correlation was not significant between the relative basal area growth of P. uviferum seedlings and \%PPFD (Figure 5).

Figure 3. Effect of microtopography on the performance of Pilgerodendron uviferum seedlings growing in bogs on different rooting substrates: (a) mortality and survival (\%) (living seedlings were divided in "live-unbrowsed" and "live-browsed"); (b) relative basal area growth $\left(\mathrm{cm}^{2} \mathrm{~cm}^{-2}\right)$; (c) relative mean shoot growth $\left(\mathrm{cm} \mathrm{cm}^{-1}\right)$; (d) foliar $\mathrm{N}$ concentrations $\left(\mathrm{mg} \cdot \mathrm{g}^{-1}\right)$; (e) foliar P concentrations $\left(\mathrm{mg} \cdot \mathrm{g}^{-1}\right)$; and (f) foliar N/P ratios (\%). Treatments: BF-Min: mineral soil below the original surface after removal of moss; BF-Flat: undisturbed flat Sphagnum layer; BF-Mound: elevated mound, raised through the addition of moss. No significant differences between treatments for the same variable in (a). Treatments with different lowercase letters were significantly different $(p \leq 0.05)$.
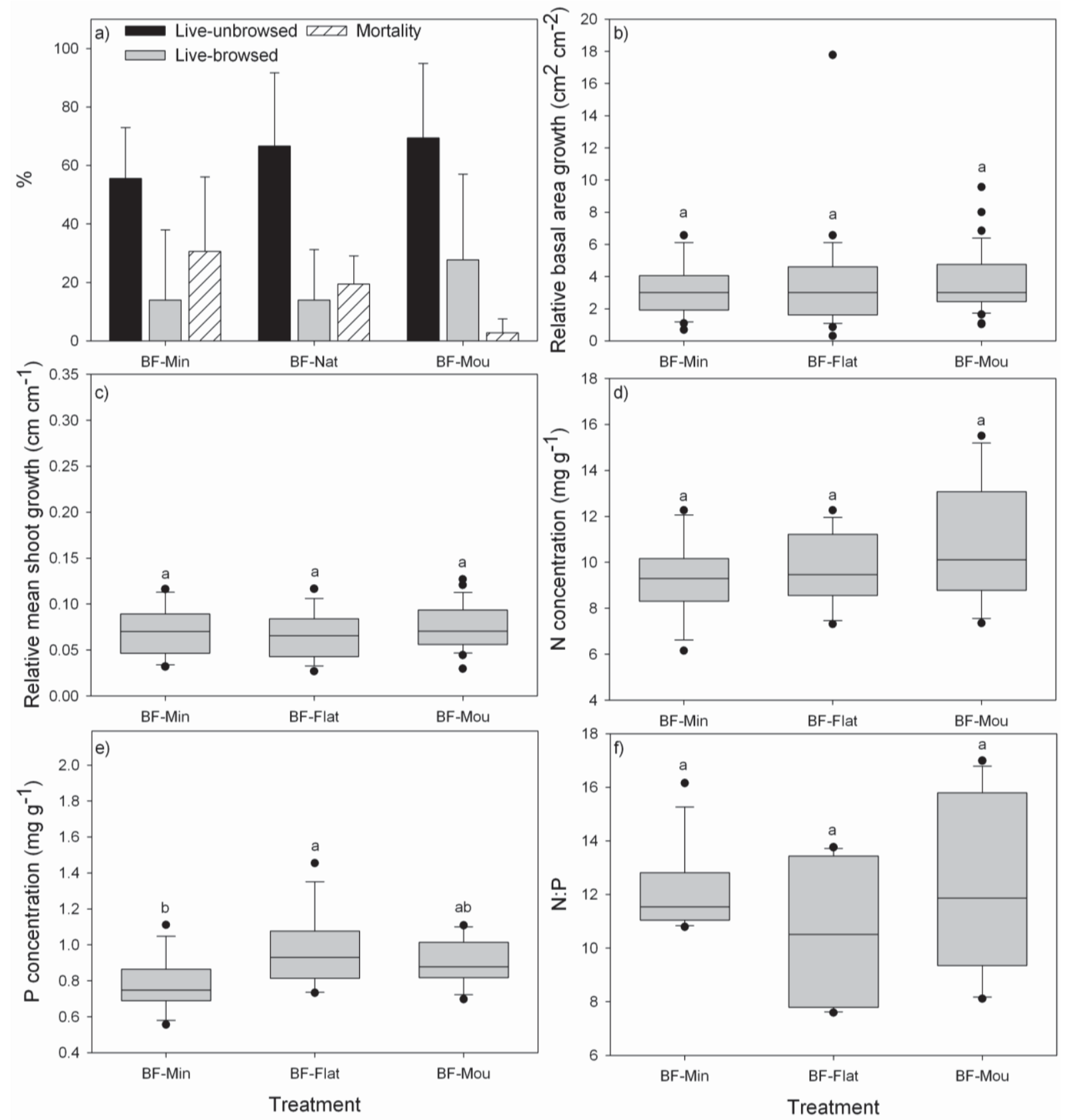
Figure 4. Effect of nurse canopy on the performance of Pilgerodendron uviferum seedlings growing in upland areas: (a) mortality and survival (\%) (living seedlings were divided in "live-unbrowsed" and "live-browsed"); (b) relative basal area growth $\left(\mathrm{cm}^{2} \mathrm{~cm}^{-2}\right)$; (c) relative mean shoot growth $\left(\mathrm{cm} \mathrm{cm}^{-1}\right)$; (d) foliar $\mathrm{N}$ concentrations $\left(\mathrm{mg} \mathrm{g}^{-1}\right)$; (e) foliar $\mathrm{P}$ concentrations $\left(\mathrm{mg} \cdot \mathrm{g}^{-1}\right)$; and (f) foliar N/P ratios (\%). Treatments: UF-Gap: small open areas; UF-50: semi-open areas, where $50 \%$ of canopy trees were thinned; UF-Den: $100 \%$ canopy cover. No significant differences between treatments for the same variable in (a). Treatments with different lowercase letters were significantly different $(p \leq 0.05)$.
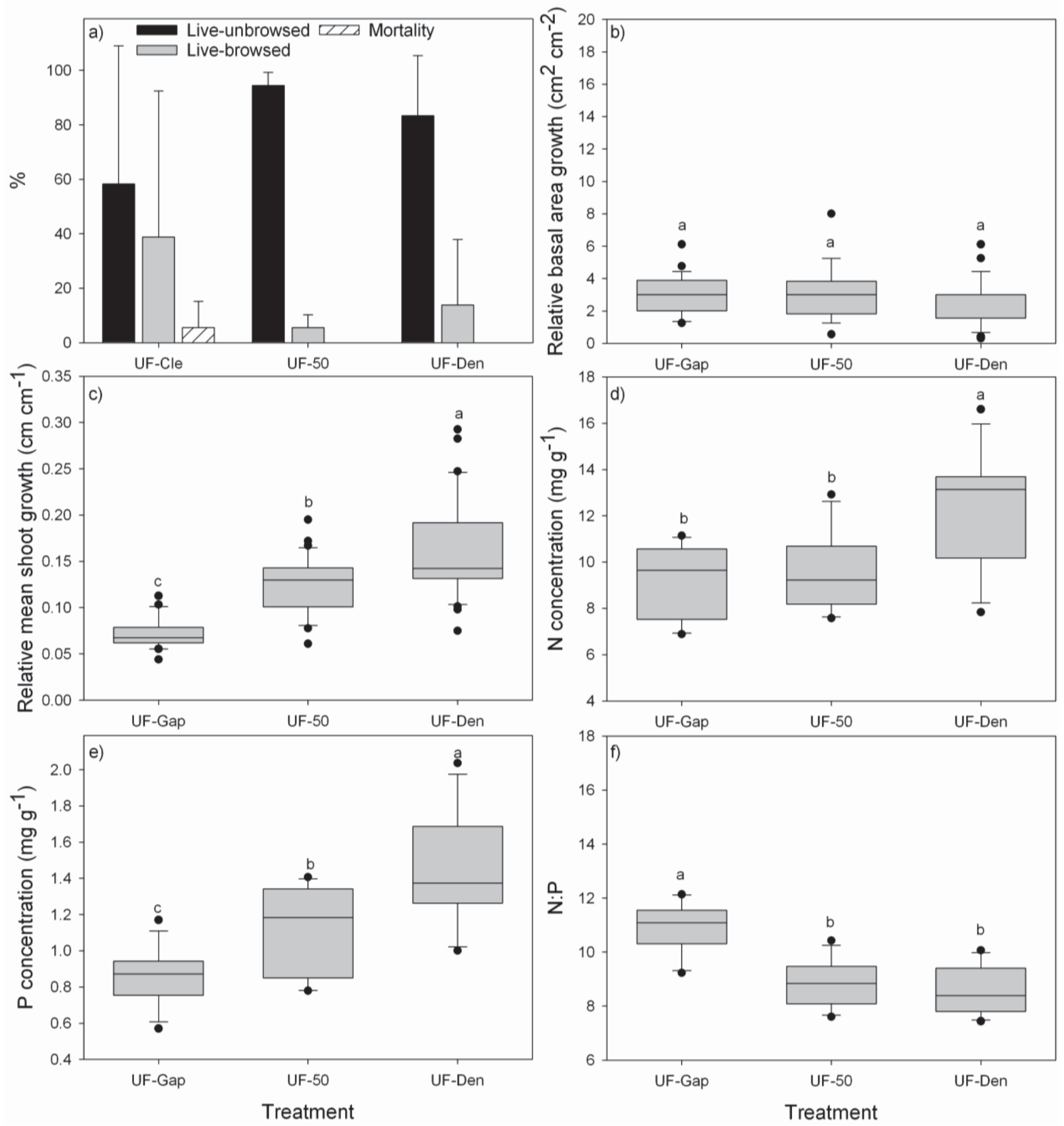
Figure 5. Relationships between (a) relative basal area growth $\left(\mathrm{cm}^{2} \mathrm{~cm}^{-2}\right)$ and \%PPFD; (b) relative mean shoot growth $\left(\mathrm{cm} \mathrm{cm}^{-1}\right)$ and \%PPFD in planted P. uviferum seedlings.
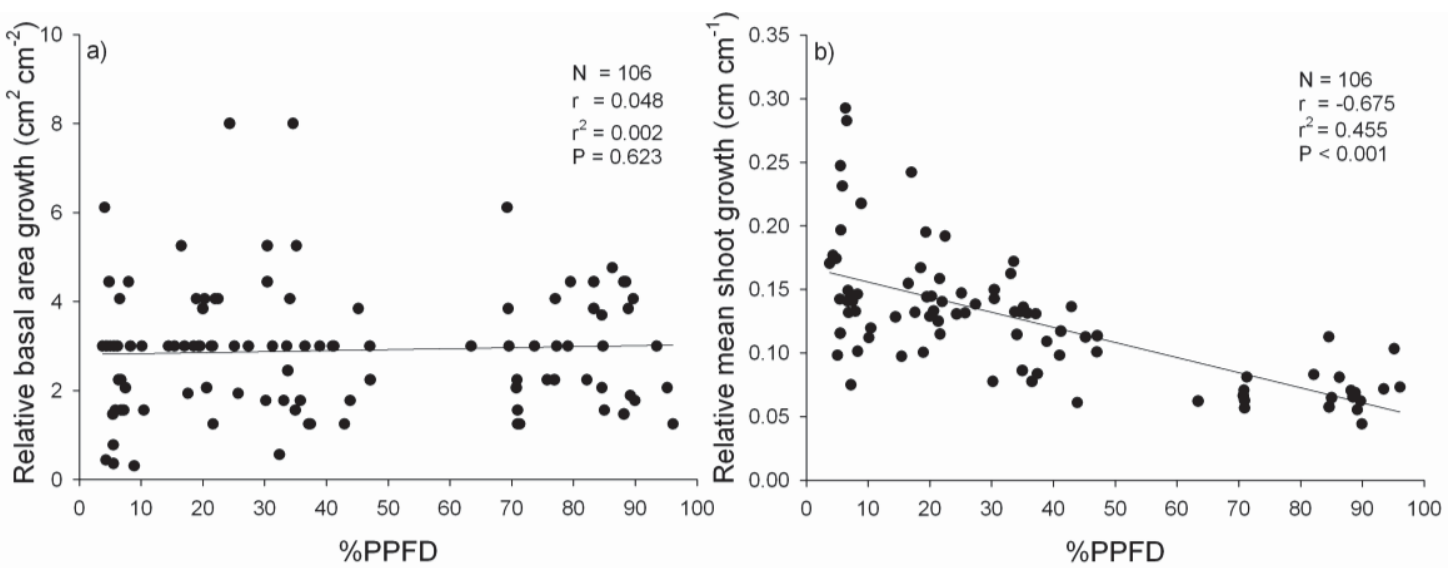

Seedlings established in gaps had almost twice the $\mathrm{CO}_{2}$ assimilation capacity $\left(A_{\max }\right)$ when compared to seedlings established beneath canopies (UF-50 and UF-Den) (Table 1). This difference between treatments is also reflected in the light saturation points (LSP). Dark respiration values $\left(R_{\mathrm{d}}\right)$ of seedlings in gaps were almost five-times higher than for those beneath canopy. In contrast, the potential photochemical quantum yield of photosystem II (Fv/Fm) was lower in seedlings established in gaps than in seedlings beneath canopy.

Table 1. Effects of light availability on photosynthesis parameters derived from light response curves for Pilgerodendron uviferum seedlings. LSP: light saturation point $\left(\mu \mathrm{mol} \mathrm{m} \mathrm{m}^{-2} \cdot \mathrm{s}^{-1}\right)$; LCP: light compensation point $\left(\mu \mathrm{mol} \mathrm{m} \mathrm{m}^{-2} \cdot \mathrm{s}^{-1}\right)$; AQE: maximal quantum yield; $A_{\max }$ : maximum net photosynthesis $\left(\mu \mathrm{mol} \mathrm{m}^{-2} \cdot \mathrm{s}^{-1}\right) ; R_{\mathrm{d}}$ : dark respiration $\left(\mu \mathrm{mol} \mathrm{m} \mathrm{m}^{-2} \cdot \mathrm{s}^{-1}\right) ; \mathrm{Fv} / \mathrm{Fm}$ : potential photochemical quantum yield of PSII; and LMA: leaf mass area $\left(\mathrm{g} \cdot \mathrm{m}^{-2}\right)$. Treatments: UF-Gap: small open areas; UF-50: semi-open areas, where $50 \%$ of canopy trees were thinned; UF-Den: $100 \%$ canopy cover.

\begin{tabular}{|c|c|c|c|c|c|c|c|}
\hline Treatment & 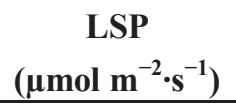 & 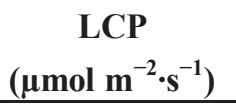 & AQE & 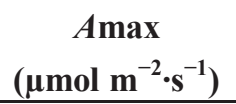 & 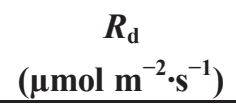 & $\mathbf{F v} / \mathbf{F m}$ & $\begin{array}{c}\text { LMA } \\
\left(\mathrm{g} \cdot \mathrm{m}^{-2}\right)\end{array}$ \\
\hline UF-Gap & $1624 \pm 117$ & $17.6 \pm 2.0$ & $0.099 \pm 0.012$ & $20.0 \pm 2.0$ & $-1.51 \pm 0.12$ & $0.78 \pm 0.01$ & $669.4 \pm 58.4$ \\
\hline UF-50 & $834 \pm 39$ & $7.6 \pm 1.2$ & $0.101 \pm 0.007$ & $9.5 \pm 0.7$ & $-0.32 \pm 0.04$ & $0.81 \pm 0.00$ & $338.7 \pm 21.3$ \\
\hline UF-Den & $746 \pm 110$ & $5.0 \pm 0.7$ & $0.111 \pm 0.016$ & $9.5 \pm 0.9$ & $-0.21 \pm 0.02$ & $0.83 \pm 0.00$ & $421.7 \pm 10.9$ \\
\hline
\end{tabular}

In seedlings growing at upland sites, net $\mathrm{CO}_{2}$ assimilation $\left(A_{\mathrm{N}}\right)$ increased with light intensity across all canopy treatments (Figure 6a). Seedlings established in gaps had higher $A_{\mathrm{N}}$ than seedlings beneath canopy (UF-50 and UF-Den) at high light intensity $\left(1200 \mu \mathrm{mol}\right.$ photons $\left.\mathrm{m}^{-2} \cdot \mathrm{s}^{-1}\right)$. However, at lower light intensities $\left(25-200 \mu \mathrm{mol}\right.$ photons $\left.\mathrm{m}^{-2} \cdot \mathrm{s}^{-1}\right), A_{\mathrm{N}}$ was similar in all canopy treatments. At low light intensities, the photosynthetic light use efficiency (PLUE) was higher in shaded or partially shaded seedlings (UF-50 and UF-Den) than in gaps (Figure 6b). With increasing light intensity, the differences in PLUE between different canopy treatments decreased. The instantaneous water use efficiency (WUEi) was similar between canopy treatments and increased with higher light intensities (Figure 6c).The maximum WUEi values occurred at medium light intensities (200-400 $\mu$ mol 
photons $\mathrm{m}^{-2} \cdot \mathrm{s}^{-1}$ ) in seedlings with some canopy protection. In seedlings established in gaps, maximum WUEi was reached at higher light intensities of $600 \mu \mathrm{mol}$ photons $\mathrm{m}^{-2} \mathrm{~s}^{-1}$, and at low light intensities they had lower WUEi values.

Figure 6. (a) Net $\mathrm{CO}_{2}$ assimilation $\left(A_{\mathrm{N}}\right)$; (b) Photosynthetic light use efficiency (PLUE); (c) Instantaneous water use efficiency (WUEi) of $P$. uviferum seedlings growing under different canopy densities. All variables were determined at 25, 50, 100, 200, 300, 400, 600, 800 and $1200 \mu \mathrm{mol}$ photons $\mathrm{m}^{-2} \cdot \mathrm{s}^{-1}$. Error bars represents standard errors. Treatments: UF-Gap: small open areas; UF-50: semi-open areas, where $50 \%$ of canopy trees were thinned; UF-Den: $100 \%$ canopy cover.

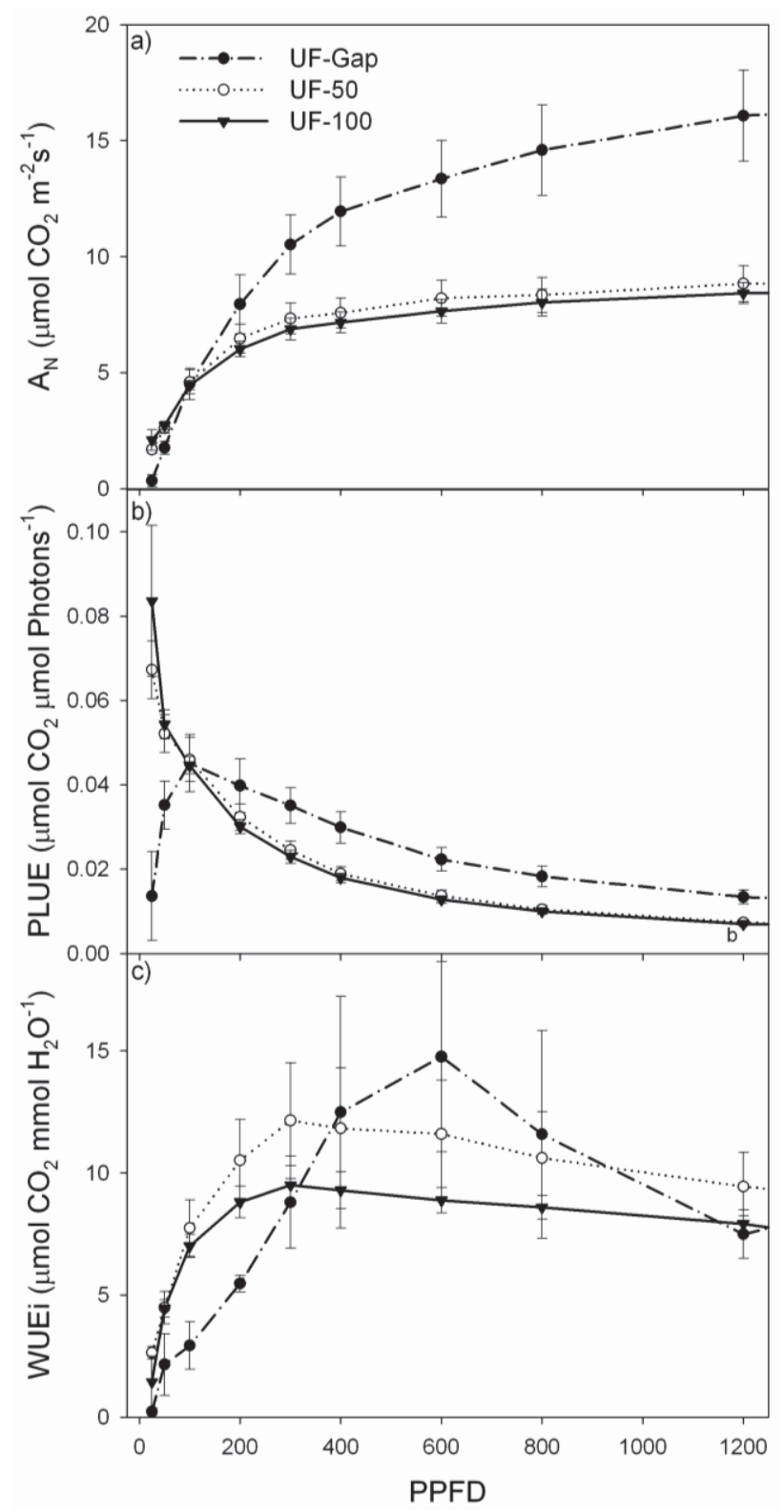

Considering seedlings of all canopy treatments together, there were no significant correlations between relative basal area growth and photosynthetic traits evaluated at different light intensities $(p>0.05)$. However, at low light intensities $\left(25 \mu \mathrm{mol}\right.$ photons $\left.\mathrm{m}^{-2} \cdot \mathrm{s}^{-1}\right)$, there were significant positive correlations $(p<0.05)$ between relative mean shoot growth and $A_{\mathrm{N}}$, WUEi and PLUE $(r=0.65,0.62$, 
0.65 , respectively). At high light intensities $\left(1200 \mu \mathrm{mol}\right.$ photons $\left.\mathrm{m}^{-2} \cdot \mathrm{s}^{-1}\right)$, these correlations were significantly negative for $A_{\mathrm{N}}$ and PLUE $(r=-0.62$, for both variables; $p<0.05)$. At intermediate light intensities, there were no significant correlations $(p>0.05)$. Additionally, there was a significant positive correlation $(r=0.73 ; p<0.01)$ between relative mean shoot growth of seedlings and the potential photochemical quantum yield of photosystem II (Fv/Fm) and significant negative correlations between relative mean shoot growth of seedlings and the light compensation point (LCP) $(r=-0.64)$, light saturation point (LSP) $(r=-0.71)$, maximum quantum yield $\left(A_{\max }\right)(r=-0.68)$, dark respiration $\left(R_{\mathrm{d}}\right)(r=-0.74)$ and leaf mass area (LMA) $(r=-0.53)($ all $p<0.05)$.

\section{Discussion}

\subsection{Performance of P. uviferum Seedlings in Bogs}

After two years of growth in bogs, there was no significant effect of the different microtopography treatments on growth and survival of $P$. uviferum seedlings. This result contradicts our first hypothesis that survival and relative growth of $P$. uviferum seedlings would be higher in elevated microsites with improved drainage and reduced competition with Sphagnum. However, the potential photochemical quantum yield of photosystem II (Fv/Fm) was higher in seedlings established on mounds, reflecting lower chronic photo-inhibition and, therefore, a more efficient photosynthetic apparatus for the photochemical use of light [19,35]. Furthermore, higher levels of Fv/Fm indicate lower environmental stress [35]. In this experiment, the Fv/Fm values may indicate reduced stress through waterlogging, which would support our second hypothesis, but there is no direct evidence for this assumption. Yet, when considering seedlings of all substrate treatments together, there was a highly significant positive correlation between the potential photochemical quantum yield of photosystem II (Fv/Fm) and the relative mean shoot growth of $P$. uviferum seedlings. In addition, seedlings planted on mounds appeared to have a lower mortality, illustrating an overall better performance than seedlings exposed to more frequent and intense waterlogging and competition with Sphagnum (Figure 3a). This is consistent with results obtained for planted P. uviferum stands in Northern Chiloé Island, where growth and survival of P. uviferum seedlings was higher on sites with less Sphagnum cover [12]. Similarly, in Picea abies bog forests in Scandinavia, elevated microsites were safer for germination of seedlings [14].

In bogs, foliar $\mathrm{N}$ and $\mathrm{P}$ concentrations were low in seedlings of all microtopography treatments, indicating that growth is likely limited by nutrient availability; an assumption that is supported by the results for nutrition of upland seedlings. Furthermore, since paludification increases soil moisture, reduces soil temperature and nutrient availability, tree nutrition is a constant problem in bog environments [36]. Obviously, changing the microtopography and, thus, the period in which root systems were partially or completely submerged, had little influence on the nutrition of seedlings, at least over the duration of this experiment. 


\subsection{Performance of P. uviferum Seedlings in Upland Areas}

In upland areas, seedlings established beneath canopies and, therefore, with reduced light availability, had lower mortality, significantly higher relative shoot growth and higher foliar $\mathrm{N}$ and $\mathrm{P}$ concentrations than seedlings established in gaps, resulting also in higher biomass (Figure 4). Furthermore, as indicated by fluorescence measurements, they appeared to be less stressed. These results are consistent with our third and fourth hypotheses that in upland stands, growth and survival of P. uviferum planted seedlings will be higher beneath a canopy and that these seedlings would have lower physiological stress. However, the underlying mechanisms for this phenomenon are not clear.

Our results are consistent with another study in Northern Chiloé, where P. uviferum seedlings established under the protection of shrubs and ferns had higher growth and survival than in open areas [12]. The significantly negative correlation between relative growth and light availability (Figure 5) strongly suggests that not light, but nutrients are limiting growth of seedlings in this environment. With the creation of gaps (of $c a .120 \mathrm{~m}^{2}$ ) we have removed the trees and shrubs that have supported mycorrhizal fungi, without which nutrient uptake would be extremely difficult and low in this environment, where most soil nutrients are held in organic form in residues of very low decomposability. Other studies have shown that the abundance and diversity of ectomycorrhizal fungal communities as seen on root tips can decline significantly in harvested sites when compared to undisturbed, adjacent forests, often as a result of fewer host trees, but also due to environmental changes [37]. And conversely, retaining live trees in otherwise clear-cut harvested areas has been shown to reduce mortality and improve the growth of regenerating seedlings by providing them with mycorrhizal networks that facilitate uptake of nutrients [38]. These mycorrhizal networks may not just develop among individuals of the same species, but also between individuals of different species $[38,39]$. Thus, we assume that the removal of vegetation to create gaps has led to a decline in mycorrhizal fungi, which affected seedling nutrition adversely. Unfortunately, we did not examine mycorrhizal colonization of the fine roots of P. uviferum under the different treatments to lend further support to this assumption and to test whether the created gaps were big enough to affect fine-root colonization by mycorrhizae.

The physiological adaptations of seedlings to the different light regimes occurring in the canopy treatments also support the assumption that seedling growth was not limited by light availability. The upland treatments covered most of the light availability gradient, from approximately $11 \%$ PPFD to almost $80 \%$. Pilgerodendron uviferum seedlings established in gaps had higher maximum rates of $\mathrm{CO}_{2}$ assimilation $\left(A_{\max }\right)$, dark respiration $\left(R_{\mathrm{d}}\right)$ and had higher light compensation (LCP) and saturation (LSP) points, which indicates light photosynthetic acclimation to high irradiance environments $[21,40]$. However, the higher $A_{\max }$ in gap seedlings did not result in higher growth rates, which were higher in the more shaded treatments (Figure 4b,c). In addition to the better nutrition of seedlings beneath canopies, this may also be related to the higher $\mathrm{C}$ costs associated with photo-protection, higher metabolic cost and concomitant higher respiration rates of seedlings growing in the open [21]. These higher $\mathrm{C}$ costs of seedlings adapted to full light may not pay off in the environment of North Patagonia, where sunny conditions prevail only for a short time in summer. For example, the nearby city of Quellón ( $\pm 25 \mathrm{~km}$ to the east) has on average 239 days of rain per year [41]. On overcast days, the midday incident PPFD above the canopy can range between 150 and $250 \mu \mathrm{mol}$ photons $\mathrm{m}^{-2} \cdot \mathrm{s}^{-1}$ 
(measured in autumn in open areas near the treatments). Therefore, although seedlings growing in the open have photosynthetic machineries that allow them to be more efficient at high irradiation (1200 $\mu \mathrm{mol}$ photons $\left.\mathrm{m}^{-2} \cdot \mathrm{s}^{-1}\right)$, at lower light intensities $\left(200 \mu \mathrm{mol}\right.$ photons $\left.\mathrm{m}^{-2} \cdot \mathrm{s}^{-1}\right)$, the photosynthesis does not saturate (LSP). At even lower light intensities $\left(<100 \mu \mathrm{mol}\right.$ photons $\left.\mathrm{m}^{-2} \cdot \mathrm{s}^{-1}\right)$, net $\mathrm{CO}_{2}$ assimilation is already higher in seedlings adapted to shady environments, such as those established beneath canopies (Figure 6). In addition, photosynthetic light use efficiency (PLUE) and instantaneous water use efficiency $\left(\mathrm{WUE}_{\mathrm{i}}\right)$ at lower light intensities were higher in seedlings established under canopy protection than in gaps (Figure 6). These findings highlight the importance of diffuse radiation and acclimation to different levels of irradiance for the growth of seedlings, as was shown previously in other regions of the world $[21,42,43]$.

Nevertheless, many studies have suggested that under nutrient limitation, there is a close correlation between foliar $\mathrm{N}$ and $\mathrm{P}$ content and photosynthetic performance [44,45]. In this context, the higher foliar $\mathrm{N}$ and $\mathrm{P}$ concentration in seedlings established beneath a canopy (UF-50 and UF-Den) may be also influencing the rates of net $\mathrm{CO}_{2}$ assimilation under lower light availabilities, especially in the nutrient limited sites of our study area [6]. The fact that this is not reflected in the relative basal area growth maybe simply related to the extremely slow diameter growth of $P$. uviferum seedlings.

\section{Implications for Restoration Plantings}

For the same study area, our previous findings suggest that in disturbed forests previously dominated by the dioecious species $P$. uviferum, planting male seedlings of the species near female trees without regeneration or planting dispersed small groups comprising male and female trees would be an inexpensive measure to accelerate the restoration of $P$. uviferum forests [10]. The principal aim of this study was to know how different site conditions affect the successful performance of P. uviferum plantings, in order to serve as background information for future restoration programs. In this context, the results of this study provide useful guidance to plant $P$. uviferum seedlings in both bog and upland sites.

In bogs:

- The high effort associated with mounding the soil is not justified since survival of seedlings established on mounds was only slightly improved and there were no effects on growth. Therefore, seedlings should be planted in the grown substrate of flat areas or on natural mounds and small elevated areas in the landscape to avoid waterlogging conditions for seedlings.

- Existing vegetation, e.g., of shrubs, such as Bacharis sp., Gaultheria sp., and ferns, such as Gleichenia sp., should not be removed or only partially removed to offer more suitable environments to seedlings [12].

In upland areas:

- The creation of gaps or strips is not effective and may be detrimental to seedling establishment and growth.

- Planting seedlings beneath existing canopies of other trees, like D. winteri, W. trichosperma, $N$. nitida or T. stipularis, is a good option to promote better nutrition and faster growth of 
P. uviferum seedlings. Under these shady conditions, P. uviferum can persist over long periods of time [6].

In this study we present for the first time data about browsing problems in P. uviferum seedlings (Figures 3 and 4). In the field, we could observe browsing by the threatened Pudu deer (Pudu pudu), one of the smallest deer in the world and endemic to Chile and Argentina [46]. Although browsing problems were low (treatments means $<39 \%$ of plants were browsed), the high incidence of it in gaps $(100 \%)$ gives further support to the recommendation that gaps are not favorable sites for seedling establishment.

The field trials of this study are an important first step to establish a scientific basis for active restoration of $P$. uviferum in degraded forests of North Patagonia that were once dominated by this species. However, afforestation trials are needed at a larger scale to enable generalization of results to the variation in landscape conditions, including, for example, different altitudes and aspects. Since P. uviferum has a limited seed dispersal potential and effective seedling recruitment distance [10], restoration plantings are an important tool within the range of potential passive and active restoration approaches.

\section{Acknowledgments}

We are especially grateful to the administration and staff of the Tantauco Park for constant support in the field. A. Caracciolo, N. Carrasco, J. Flade and D. Rieck assisted under difficult conditions in the field. Without their help, this study could not have been done. For assistance in the laboratory, we thank R. Nitschke. S. Gärtner helped with statistical advice. Also, we would like to thank three anonymous reviewers for their useful comments. J. Bannister received a DAAD-CONICYT scholarship to support his Ph.D. studies at the University of Freiburg, where he participated in the graduate school "Environment, Society and Global Change". This research was also financially supported through grants by the Georg-Ludwig-Hartig and Futuro Foundations. The article processing charge was funded by the German Research Foundation (DFG) and the Albert Ludwigs University Freiburg in the funding programme Open Access Publishing.

\section{Conflict of Interest}

The authors declare no conflict of interest.

\section{References}

1. Hobbs, R.J.; Norton, D.A. Towards a conceptual framework for restoration ecology. Restor. Ecol. 1996, 4, 93-110.

2. Benayas, J.M.R.; Bullock, J.M.; Newton, A.C. Creating woodland islets to reconcile ecological restoration, conservation and agricultural land use. Front. Ecol. Environ. 2008, 6, 329-336.

3. Morrison, E.B.; Lindell, C.A. Active or passive forest restoration? Assessing restoration alternatives with avian foraging behavior. Restor. Ecol. 2011, 19, 170-177.

4. Holl, K.D.; Aide, T.M. When and where to actively restore ecosystems? For. Ecol. Manag. 2011, 261, 1558-1563. 
5. Lara, A.; Donoso, C.; Escobar, B.; Rovere, A.; Premoli, A.; Soto, D.P.; Bannister, J.R. Pilgerodendron uviferum (D. Don) Florin. In Las Especies Arbóreas de los Bosques Templados de Chile y Argentina, Autoecología; Donoso, C., Ed.; Marisa Cuneo: Valdivia, Chile, 2006; pp. 82-91.

6. Bannister, J.R.; Donoso, P.J.; Bauhus, J. Persistence of the slow growing conifer Pilgerodendron uviferum in old-growth and fire-disturbed southern bog forests. Ecosystems 2012, 15, 1158-1172.

7. Bannister, J.R.; Lara, A.; Le Quesne, C. Estructura y dinámica de bosques de Pilgerodendron uviferum afectados por incendios en la Cordillera de la Costa de la Isla Grande de Chiloé. Bosque 2008, 29, 33-43.

8. Walter, K.S.; Gillet, H.J. 1997 IUCN Red List of Threatened Plants; IUCN: Cambridge, UK, 1998.

9. Hobbs, R.J.; Norton, D.A. Ecological Filters, Thresholds and Gradients in Resistance to Ecosystem Reassembly. In Assembly Rules and Restoration Ecology: Bridging the Gap between Theory and Practice; Temperton, V.M., Hobbs, R.J., Nuttle, T., Halle, S., Eds.; Island Press: Washington, DC, USA, 2004; pp. 72-95.

10. Bannister, J.R.; Wagner, S.; Donoso, P.J.; Bauhus, J. The importance of seed trees for the passive restoration of disturbed Pilgerodendron uviferum bog forests in Northern Patagonia. Unpublished work, 2013.

11. Armesto, J.J.; Bustamante-Sánchez, M.A.; Díaz, M.F.; González, M.E.; Holz, A.; Nuñez-Avila, M.; Smith-Ramirez, C. Fire Disturbance Regimes, Ecosystem Recovery and Restoration Strategies in Mediterranean and Temperate Regions of Chile. In Fire Effects on Soils and Restoration Strategies; Cerda, A., Robichaud, P.R., Eds.; Science Publishers: Enfield, NH, USA, 2009; pp. 537-564.

12. Carmona, M.R.; Aravena, J.C.; Bustamante-Sanchez, M.A.; Celis-Diez, J.L.; Charrier, A.; Díaz, I.A.; Díaz-Forestier, J.; Díaz, M.F.; Gaxiola, A.; Gutiérrez, A.G.; et al. Estación biológica Senda Darwin: Investigación ecológica de largo plazo en la interfase ciencia-sociedad. Rev. Chil. Hist. Nat. 2010, 83, 113-142.

13. Lara, A.; Echeverría, C.; Thiers, O.; Huss, E.; Escobar, B.; Tripp, K.; Zamorano, C.; Altamirano, A. Restauración ecológica de coníferas longevas: el caso del alerce (Fitzroya cupressoides) en el sur de Chile. In Restauración de Bosques en América Latina; González-Espinosa, M., Rey-Benayas, J.M., Ramírez-Marcial, N., Eds.; Mundi-Prensa México: México City, México, 2008; pp. 40-55.

14. Hörnberg, G.; Ohlson, M.; Zackrisson, O. Influence of bryophytes and microrelief conditions on Picea abies seed regeneration patterns in boreal old-growth swamp forests. Can. J. For. Res. 1997, 27, 1015-1023.

15. Ohlson, M. Growth and nutrient characteristics in bog and fen populations of Scots pine (Pinus sylvestris). Plant Soil 1995, 172, 235-245.

16. Díaz, M.; Armesto, J.J. Limitantes físicos y bióticos de la regeneración arbórea en matorrales sucesionales de la Isla Grande de Chiloé, Chile. Rev. Chil. Hist. Nat. 2007, 80, 13-26.

17. Rydin, H.; Jeglum, J.K. The Biology of Peatlands; Oxford University Press: Oxford, UK, 2006. 
18. Cruz, G.; Lara, A. Tipificación, cambio de estructura y normas de manejo para Ciprés de las Guaitecas (Pilgerodendron uviferum D. Don Florin) en la isla Grande de Chiloé. Forest Engineer Thesis, Universidad de Chile, Santiago, Chile, 1981.

19. Baker, N.R.; Rosenqvist, E. Applications of chlorophyll fluorescence can improve crop production strategies: An examination of future possibilities. J. Exp. Bot. 2004, 55, 1607-1621.

20. Walters, R.G. Towards an understanding of photosynthetic acclimation. J. Exp. Bot. 2005, 56, 435-447.

21. Givnish, T. Adaptation to sun and shade: A whole-plant perspective. Funct. Plant Biol. 1988, 15, 63-92.

22. Holz, A.; Veblen, T.T. The amplifying effects of humans on fire regimes in temperate rainforests in western Patagonia. Palaeogeogr. Palaeoclimatol. Palaeoecol. 2011, 311, 82-92.

23. Di Castri, F.; Hajek, E. Bioclimatología de Chile; Vicerrectoría Académica de la Universidad Católica de Chile: Santiago, Chile, 1976.

24. Bannister, J.R.; Vidal, O.J.; Teneb, E.; Sandoval, V. Latitudinal patterns and regionalization of plant diversity along a 4270-km gradient in continental Chile. Austral Ecol. 2012, 37, 500-509.

25. Pérez, C.A.; Armesto, J.J.; Torrealba, C.; Carmona, M.R. Litterfall dynamics and nitrogen use efficiency in two evergreen temperate rainforests of southern Chile. Austral Ecol. 2008, 28, 591-600.

26. Villagrán, C. Late quaternary vegetation of southern Isla Grande de Chiloé, Chile. Quat. Res. 1988, 29, 294-306.

27. Donoso, C.; Sandoval, V.; Grez, R.; Rodríguez, J. Dynamics of Fitzroya cupressoides forests in southern Chile. J. Veg. Sci. 1993, 4, 303-312.

28. Parent, S.; Messier, C. A simple and efficient method to estimate microsite light availability under a forest canopy. Can. J. For. Res. 1996, 26, 151-154.

29. König, N. Handbuch Forstliche Analytik: Gessellschaft für Analytik; Bundesministerium für Verbraucherschutz, Ernährung und Landwirtschaft: Bonn, Germany, 2005.

30. Genty, B.; Briantais, J.M. The relationship between the quantum yield of photosynthetic electron transport and quenching of chlorophyll fluorescence. Biochim. Biophys. Acta 1989, 990, 87-92.

31. Hurlbert, S.H. Pseudoreplication and the design of ecological field experiments. Ecol. Monogr. 1984, 54, 187-211.

32. SPSS Inc. SPSS Statistics for Windows, version 17; SPSS Inc.: Chicago, IL, USA, 2008.

33. R Development Core Team. $R$ : A Language and Environment for Statistical Computing; R Foundation for Statistical Computing: Vienna, Austria, 2012.

34. Koerselman, W.; Meuleman, A.F.M. The vegetation N:P ratio: A new tool to detect the nature of nutrient limitation. J. Appl. Ecol. 1996, 33, 1441-1450.

35. Maxwell, K.; Johnson, G.N. Chlorophyll fluorescence-A practical guide. J. Exp. Bot. 2000, 51, 659-668.

36. Simard, M.; Lecomte, N.; Bergeron, Y.; Bernier, P.Y.; Paré, D. Forest productivity decline caused by successional paludification of Boreal soils. Ecol. Appl. 2007, 17, 1619-1637.

37. Jones, M.D.; Durall, D.M.; Cairney, J.W.G. Ectomycorrhizal fungal communities in young forest stands regenerating after clearcut logging. New Phytol. 2003, 157, 399-422. 
38. Simard, S.W. The foundational role of mycorrhizal networks in self-organization of interior Douglas-fir forests. Forest Ecol. Manag. 2009, 258, S95-S107.

39. Simard, S.W.; Beiler, K.J.; Bingham, M.A.; Deslippe, J.R.; Philip, L.J.; Teste, F.P. Mycorrhizal networks: Mechanisms, ecology and modelling. Fungal Biol. Rev. 2012, 26, 39-60.

40. Coopman, R.E.; Reyes-Díaz, M.; Briceño, V.F.; Corcuera, L.J.; Cabrera, H.M.; Bravo, L.A. Changes during early development in photosynthetic light acclimation capacity explain the shade to sun transition in Nothofagus nitida. Tree Physiol. 2008, 28, 1561-1571.

41. Dirección Meteorológica de Chile (DMC). Estadística Climatológica: Tomo III; Dirección Meteorológica de Chile: Santiago, Chile, 2001.

42. Roderick, M.; Farquhar, G.; Berry, S.; Noble, I. On the direct effect of clouds and atmospheric particles on the productivity and structure of vegetation. Oecologia 2001, 129, 21-30.

43. Alton, P.B.; North, P.R.; Los, S.O. The impact of diffuse sunlight on canopy light-use efficiency, gross photosynthetic product and net ecosystem exchange in three forest biomes. Glob. Chang. Biol. 2007, 13, 776-787.

44. Reich, P.; Oleksyn, J.; Wright, I. Leaf phosphorus influences the photosynthesis-nitrogen relation: A cross-biome analysis of 314 species. Oecologia 2009, 160, 207-212.

45. Mercado, L.M.; Patiño, S.; Domingues, T.F.; Fyllas, N.M.; Weedon, G.P.; Sitch, S.; Quesada, C.A.; Phillips, O.L.; Aragão, L.E.; Malhi, Y.; et al. Variations in Amazon forest productivity correlated with foliar nutrients and modeled rates of photosynthetic carbon supply. Phil. Trans. R. Soc. B 2011, 366, 3316-3329.

46. Silva-Rodriguez, E.A.; Verdugo, C.; Alejandro Aleuy, O.; Sanderson, J.G.; Ortega-Solis, G.R.; Osorio-Zuniga, F.; Gonzalez-Acuna, D. Evaluating mortality sources for the vulnerable Pudu Pudu puda in Chile: Implications for the conservation of a threatened deer. Oryx 2010, 44, 97-103.

(C) 2013 by the authors; licensee MDPI, Basel, Switzerland. This article is an open access article distributed under the terms and conditions of the Creative Commons Attribution license (http://creativecommons.org/licenses/by/3.0/). 